6. Бутковский В.А., Мельников А.М. Технология мукомольного, крупяного и комбикормового производства: учебник. Москва: Агропромиздат, 1989. 463 c.

7. Айзикович Л.Е., Сенаторский Б.В., Соколов Н.П. Новое в технологии мукомольного производства: учебник. Москва: Высшая школа, 1966. 126 с.

8. Казаков Е.Д. Влага в зерне: учебник. Москва: Колос, 1969. 51 .

9. Шпаар Дитер, Кукуруза: выращивание, уборка, хранение и использование: учебник. Киев: ИД «Зерно», 2012. $462 c$.

10. Задорожний І.М., Гаврилишин В.В. Товарознавство продовольчих товарів. Зерноборошняні товари: підручник для студентів вищих навчальних закладів. Львів: Компакт ЛВ, 2004. 304 с.

11. Циков В.С. Кукуруза: технология, гибриды, семена: учебник. Днепропетровск: Издательство Зоря, 2003.296 с.

12. Драгнев С.В., Железная Т.А., Гелетуха Г.Г. Возможности заготовки побочной продукиии кукурузы на зерно для энергетического использования в Украине. Киев, 2016. 110 с. (Аналитическая записка БАУ №16., "Биоэнергетическая ассоииация Украиныл»).

Надійшла 02.02.2019. Рецензія 10.02.2019

До друку 25.02.2019.

Адреса для переписки:

65039, Odessa, str. Kanatnaya 112,

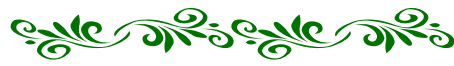

(097) 997-44-83, bunyak.e.v@gmail.com

D. ZHYGYNOV ${ }^{1}$, Dr. Tech. Sciences, Associate Professor, V. KOVALOVA ${ }^{1}$, Post-graduate Student, A. DRAGOMYR ${ }^{1}$, H. ZHYHUNOVA ${ }^{2}$, Master Student, K. ZHANABAYEVA ${ }^{3}$, Senior teacher

${ }^{1}$ Odessa National Academy of Food Technologies, Odessa, Ukraine

${ }^{2}$ The Higher Institute of Agriculture, Lille, France

${ }^{3}$ Kostanay State University named Akhmet Baytursynov, Kostanay, Kazakhstan

\title{
ANALYSIS OF THE QUALITY OF FLOUR FROM DIFFERENT SYSTEMS OF THE TECHNOLOGICAL PROCESS OF A FLOUR MILL
}

\begin{abstract}
Research in the article is aimed to determining the quality of flour from different systems of the technological process of a wheat milling. Samples of flour were obtained at the mill "Rivne Boroshno". Private enterprise "Rivne Boroshno" is one of the largest producers of wheat flour in the western region with a capacity of 180 tons /day. Flour obtained from various systems of milling process, has a very large variety of quality indicators. Whiteness, Gluten Deformation Index, Gluten Content, Protein Content, Ash Content, Water Absorbing Capacity, FN, SD, the rheological properties of dough on the Mixolab device, as well as the quality of baked bread have been evaluated.

During the study, the variability of flour quality indicators on various systems was found. Whiteness varied - from 1 to 71 units, Gluten Deformation Index - from 40 to 100 units, Gluten Content-from 2 to $36 \%$, Protein Content-from 9,8 to 18,2 \%, the FN - from 275 to $374 \mathrm{~s}, \mathrm{SD}$ - from 15 to 30,3 UCD, Ash Content - from 0,31 to 2,23\%, Water Absorbing Capacity - from 53,5 to $69,7 \%$.

In the process of grinding grain and intermediate products, more than twenty flour streams of different quality are produced at the flour mill. From these streams it is required to receive only one or several grades of flour. Naturally, if only one variety is produced, then all flows from different systems are sent to it. The weighted average quality indicators of flour should comply with the requirements of the standard for this grade in terms of Ash Content, Gluten Content, etc.

The maximum Ash Content is observed in the streams from the last reduction systems, as well as from break systems in the milling process, where products with a large number of brans are milled. At the same time, the flour from the central parts of the endosperm is slightly less gluten, but more starch than in the flour from the peripheral parts of the endosperm, which are grinding on subsequent reduction systems.

For the research, samples of flour were taken from each system of the technological process. For convenience, we have arranged them for quality using the indicator of whiteness. One of the main indicators of the quality of flour, which determines its grade, is whiteness. In the studied samples, the values of the whiteness index range from 71 to 1 unit.
\end{abstract}

Key words: flour quality, wheat flour, quality indicators, gluten, protein, Falling Number, Starch Damage

\section{Introduction}

Bread products vary widely around the world, as do their production techniques. Basic ingredients are cereal flour, water, yeast or another leavening agent, and salt $[1,2]$. Wheat is one of the cereals used extensively in many parts of the world for the preparation of bread and many bakery products $[3,4]$. Flour performance depends on its composition, which in turn depends on wheat characteristics and milling. Milling separates the bran and germ fractions from the endosperm, which is used to make flour, and reduces endosperm particles to the correct size [5].

Flours differ in their extraction rate, which is defined as the proportion of flour by weight, derived by 
milling from a known quantity of grains [6].

Commercial wheat flour milling produces a large number of flour fractions, or mill streams, that are recombined to provide flours with specific processing characteristics. Each mill stream varies in its composition and functional characteristics as a result of the irregular distribution of components within the wheat kernel [7].

The flour fractions that separated at different technological stages are generally mixed to fulfill economic, qualitative and nutritional constraints and to provide flours with specific technological characteristic. The quality of the resulting flour is given by the composition of the different mill streams that are selected for blending and the functionality of the different components [8-10].

Milling fractions contain endosperm, aleurone, pericarp, seed coat, and germ material in different proportions. As wheat components are not uniformly distributed over the wheat kernel, the obtained milling fractions differ in composition as well as in functional properties. The miller can combine all flour streams to produce straight-run flour. The quality of such flour depends not only on the milling process itself but also on the wheat selected for milling $[11,12,13]$.

The bread yield and volume depend on a large number of factors, such as gluten content, ash content, number of falling, rheological characteristics, etc., which do not independently characterize the baking process of the bread and should be determined comprehensively to receive overall picture of wheat end-use performance potential [14].

\section{Materials and methods}

Hard wheat was milled in an industrial roller mill (private enterprise "Rivne Boroshno") to an extraction rate of $78 \%$. The industrial roller mill consisted on four break rolls, ten reduction rolls, five bran finisher and three break reduced fraction.

The obtained wheat mill streams consisted of 8 break flour fractions $(\mathrm{B} 1 / \mathrm{B} 2 \mathrm{~A}, \mathrm{~B} 1 / \mathrm{B} 2 \mathrm{~B}, \mathrm{~B} 1 / \mathrm{B} 2 \mathrm{C}, \mathrm{B} 3 \mathrm{~A}$, $\mathrm{B} 3 \mathrm{~B}, \mathrm{~B} 4 \mathrm{~A}, \mathrm{~B} 4 \mathrm{~B}, \mathrm{~B} 5 \mathrm{AB}), 19$ reduction flour fractions (C1AC(1), C1AC(2), C1AF(1), C1AF(2), C2AA(1), $\mathrm{C} 2 \mathrm{AA}(2), \mathrm{C} 2 \mathrm{AB}(1), \mathrm{C} 2 \mathrm{AB}(2), \mathrm{C} 3(1), \mathrm{C} 3(2), \mathrm{C} 4, \mathrm{C} 5(1)$, $\mathrm{C} 5(2), \mathrm{C} 6, \mathrm{C} 7(1), \mathrm{C} 7(2), \mathrm{C} 8, \mathrm{C} 9, \mathrm{C}(10)$, four break reducing fraction (Div1(1), Div1(2), Div2, Div3) and four sizing flour fractions $(\mathrm{C} 1 \mathrm{~B}(1), \mathrm{C} 1 \mathrm{~B}(2), \mathrm{C} 2 \mathrm{~B}(1), \mathrm{C} 2 \mathrm{~B}(2))$.

The physical-chemical characteristics of the wheat and flour were evaluated as follows: Moisture con

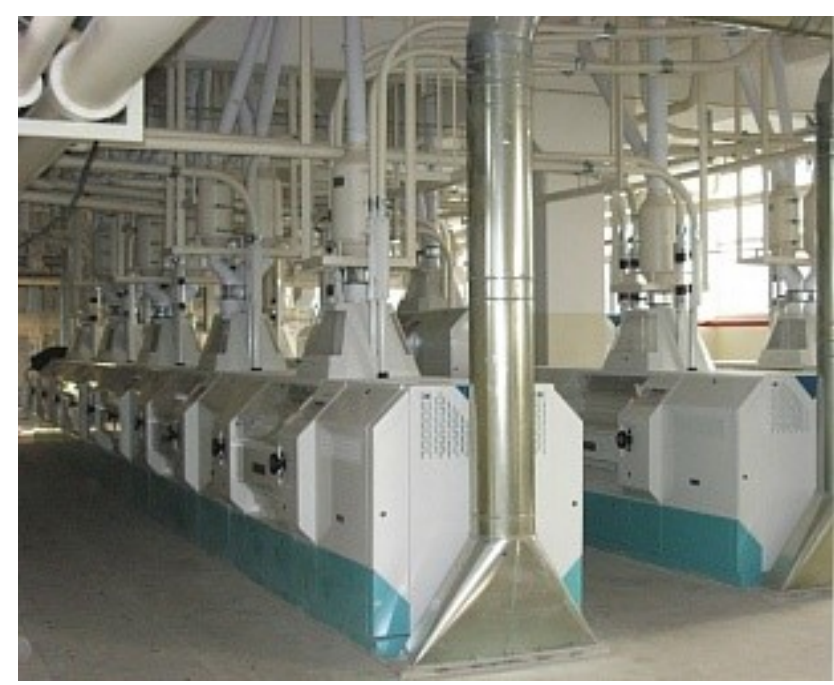

tent through the GOST 13586.5-2015 method; Whiteness through the GOST 26361-2013 method; Wet Gluten Content through the GOST 27839-2013 method; FN through the ISO 3093:2009 method; Ash Content through the ISO 2171:2007 method; SD through the ISO 17715:2013 method; rheological characteristics were tested with the Chopin Mixolab through the ISO 177182015 method.

\section{Results and discussions}

The highest whiteness index was in the flour selected from the systems: $\mathrm{C} 1 \mathrm{AC}(1), \mathrm{C} 1 \mathrm{AF}(1), \mathrm{C} 1 \mathrm{AC}(2)$, $\mathrm{C} 2 \mathrm{AA}(1), \mathrm{C} 2 \mathrm{AB}(1), \mathrm{C} 2 \mathrm{~B}(1)$, because the first grinding systems process the intermediate products with the least amount of shells and get the highest quality flour (Fig. 1). The lowest indicators of whiteness possessed flour from the systems: C9, B5AB, C8, C10. On these systems, the product with the highest amount of bran is processed, thereby reducing the whiteness of the flour. In accordance to GSTU 46.004-99 for flour of the highest grade, the whiteness must be not less than 54 units; for flour of the first grade - from 36,0 to 53,0 units; for flour of the second grade - from 12,0 to 35,0 units. Flour selected from the systems: $\mathrm{C} 1 \mathrm{AC}(1 \mathrm{~m}), \mathrm{C} 1 \mathrm{AF}(1 \mathrm{~m})$, $\mathrm{C} 1 \mathrm{AC}(2 \mathrm{~m}), \quad \mathrm{C} 2 \mathrm{AA}(1 \mathrm{~m}), \quad \mathrm{C} 2 \mathrm{AB}(1 \mathrm{~m}), \quad \mathrm{C} 2 \mathrm{~B}(1 \mathrm{~m})$, $\mathrm{C} 1 \mathrm{~B}(1 \mathrm{~m}), \quad \mathrm{C} 1 \mathrm{AF}(2 \mathrm{~m}), \quad \mathrm{C} 1 \mathrm{~B}(2 \mathrm{~m}), \quad \mathrm{C} 2 \mathrm{AA}(2 \mathrm{~m})$, $\mathrm{C} 2 \mathrm{AB}(2 \mathrm{~m}), \mathrm{C} 4, \mathrm{C} 2 \mathrm{~B}(2 \mathrm{~m}), \mathrm{C} 3(1 \mathrm{~m}), \mathrm{C} 3(2 \mathrm{~m}), \mathrm{C} 6$ has the whiteness corresponding to the whiteness of the highest grade. Ash content has great importance for controlling the separation of the brans from the endosperm and

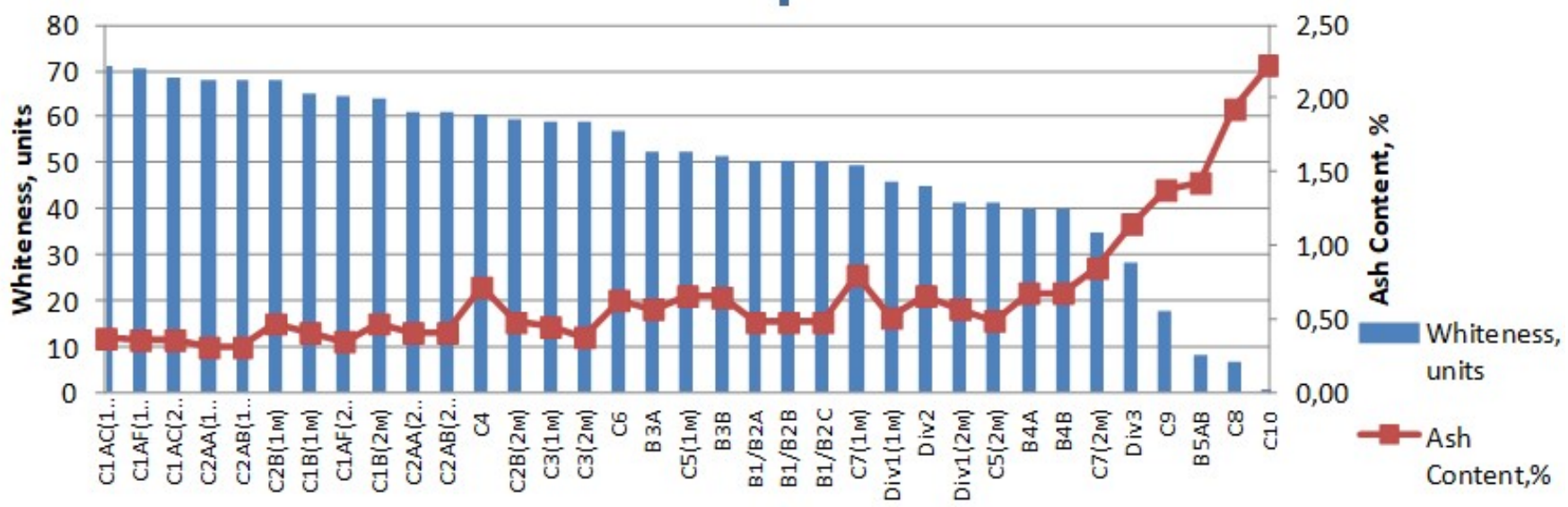

Fig. 1. Whiteness and Ash Content of flour streams 


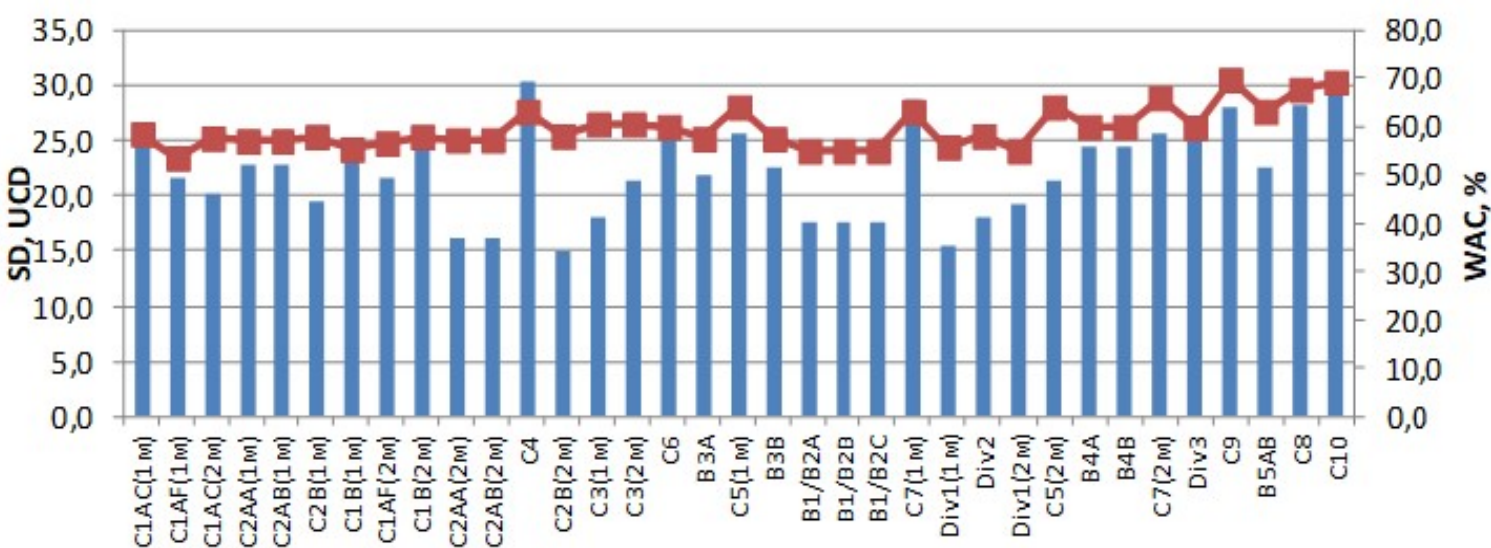

80,0

70,0

60,0

50,0 ๙०

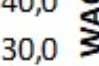

20,0

SD,UCD

Fig. 2. Starch damage and Water Absorption Capacity of flour streams

assessing the quality of flour. This is because the bran and the aleurone layer contain significantly more minerals than the endosperm.

The structure of the flour test is due not only to the quantity of proteins, but mainly to their structure and mechanical properties, these properties affect the ability of the protein in flour to hold different amounts of water, that is, on the water absorption capacity of the flour.

The dispersibility of flour affects on its water absorption capacity. Due to the damage to the starch grains, the Water Absorbing Capacity of the flour increases. The ability of starchy flour grains to absorb moisture depends on many factors. One of them is the partial dispersion of starch grains during grinding the grain into flour. The amount of SD increases the hydrophilicity of starch and the intensity of its hydrolysis by amylolytic enzymes. A high level of damaged starch results in dough sticking to hands and equipment. Water Absorbing Capacity of most of the samples have high enough indicators from 55,0 to $69,7 \%$ (Fig. 2). Flour samples from systems C4 30,3 UCD, C7 - 28,6 UCD and C10 - 29,6 UCD have the highest rate of Starch Damage.

The proteins that make up gluten are found in the endosperm of wheat grain. Their quantity and properties determine the baking qualities of wheat flour that produced from this grain. For wheat with gluten of normal quality, there is a direct relationship between the protein content, and, therefore, gluten, in flour and its potential baking ability, that is, the ability to give good bread in the most favorable baking conditions for this flour. The proteins that forming gluten give it structural and mechanical properties, such as plasticity, elasticity, stretchability, which indicates the quality of gluten.

In accordance to GSTU 46.004-99 for flour of the highest grade, the Wet Gluten Content must be not less than $24,0 \%$, for flour of the first grade - not less than $25,0 \%$, for flour of the second grade - not less than $21,0 \%$. The greatest amount of gluten is on the systems B5AB, B4A, B4B - 36,4 \% (Fig. 3). On the same systems, the amount of protein in the flour is greatest. Least gluten in flour from the system $\mathrm{C} 10-2 \%$, this can be explained by the fact that this system is processed much more bran than the endosperm, in which gluten is found.

The FN is used to characterize the activity of amylolytic enzymes (amylases) contained in the grain or flour. FN of wheat flour, depending on its quality, can vary widely. By the activity of amylase can be adjudicated on the activity of the other enzymes in the flour. If the activity of amylase is increased, then the activity of proteolytic enzymes that cause the destruction of gluten will be high. If the activity of $\alpha$-amylase is reduced, then proteases will have a weak effect on gluten proteins. Under the influence of highly active proteases, gluten becomes too weak, and the dough is very blurred. The accumulation of dextrins and the weakening of gluten leads to a noticeable deterioration in the quality of bread. In accordance to GSTU 46.004-99 for high-grade flour, the

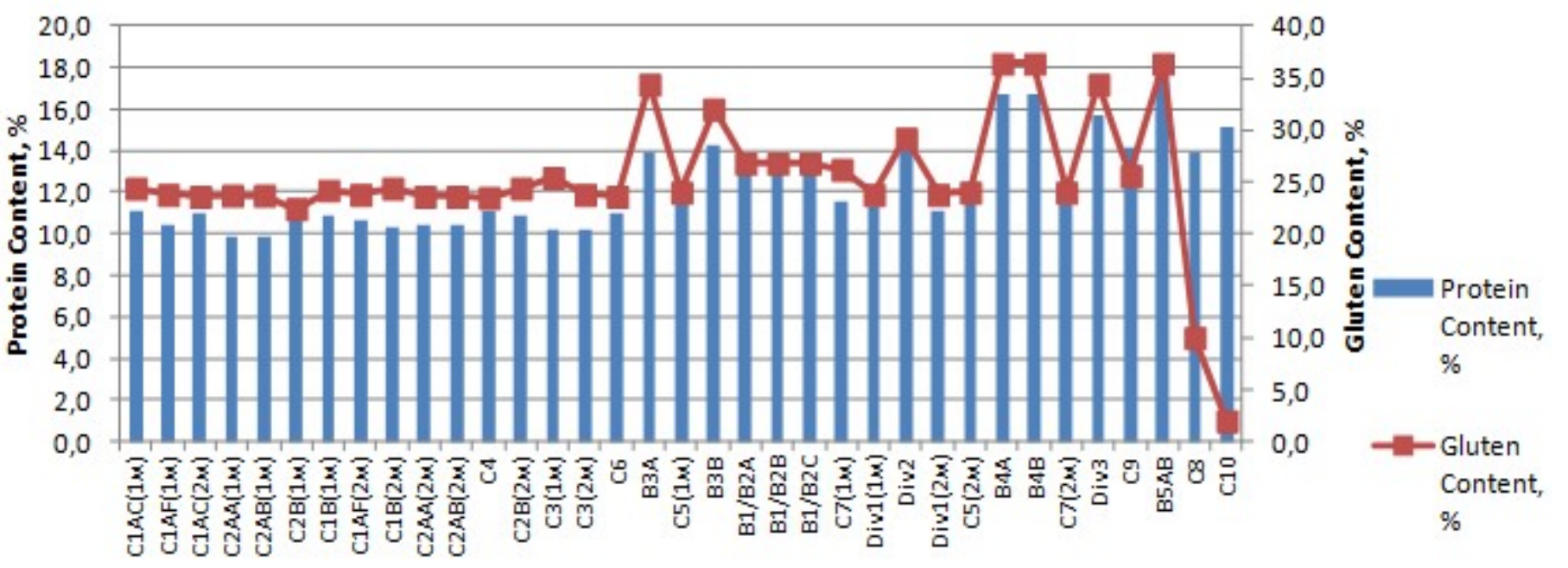

Fig. 3. Protein and Gluten Content of flour streams 


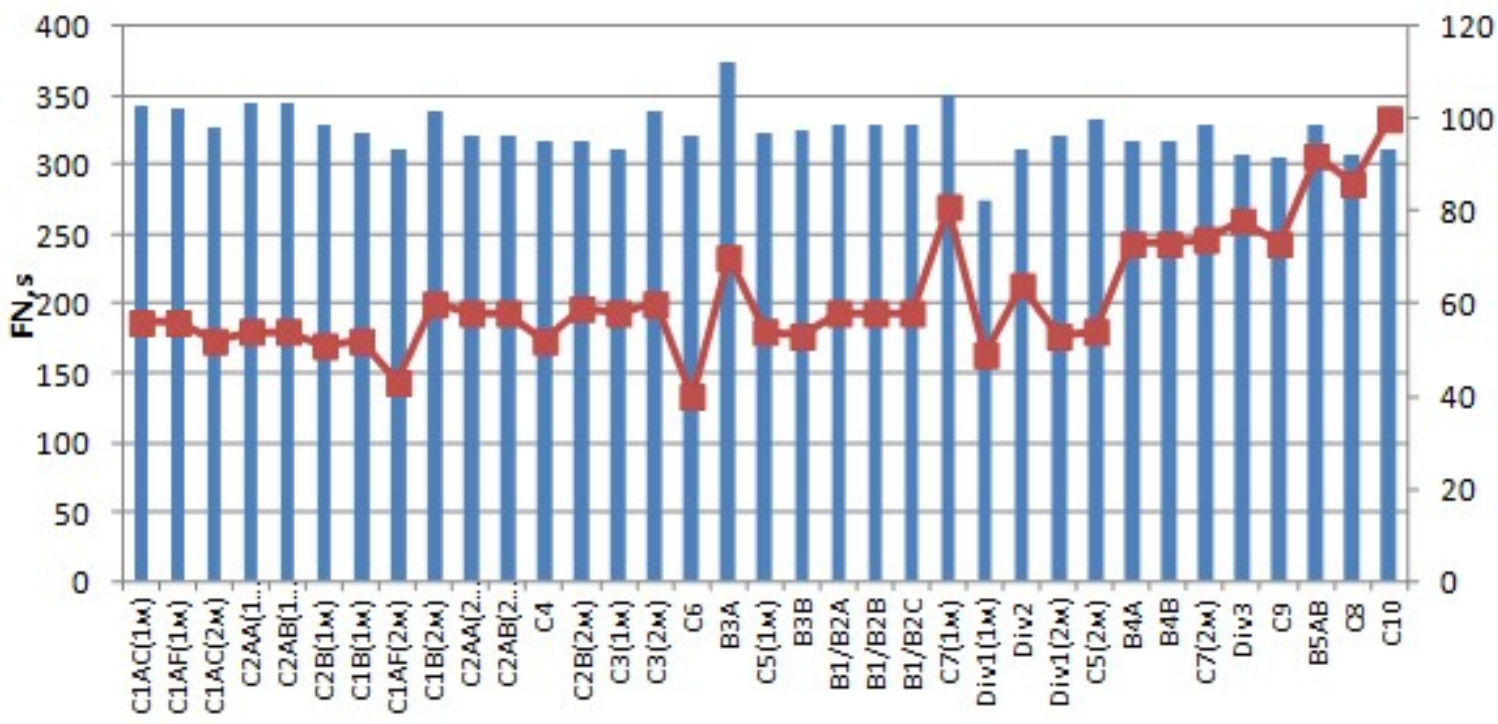

Fig. 4. Falling Number and Gluten Deformation Index of flour streams

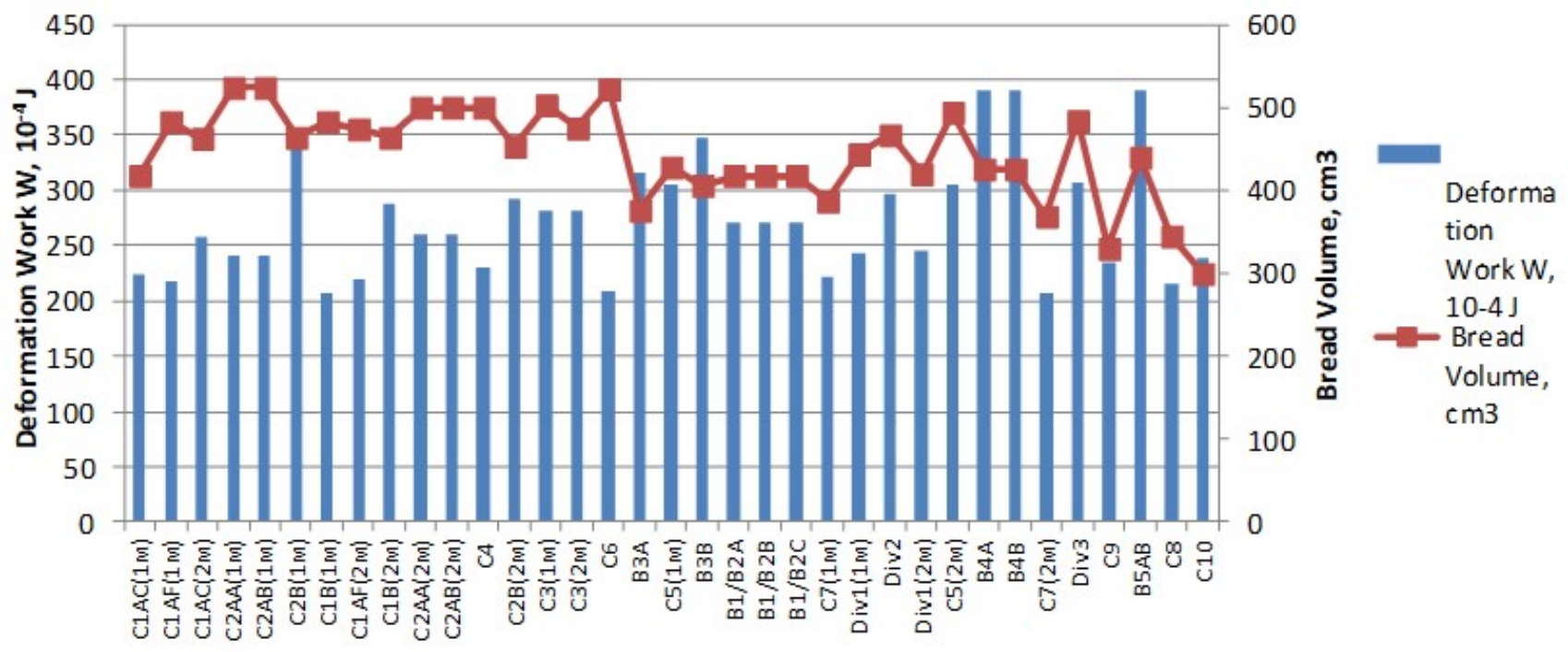

Fig. 5. Deformation Work and Bread Volume of flour streams

FN must be at least $160 \mathrm{~s}$. The highest FN were found in flour from systems B3A - $374 \mathrm{~s}, \mathrm{C} 7-350 \mathrm{~s}, \mathrm{C} 2 \mathrm{AA}-$ 344 s, C2AB - 344 s (Fig. 4). The lowest - on the Div(1) $-275 \mathrm{~s}$. The optimal FN for bakery wheat flour is - from 230 to $330 \mathrm{~s}$.

The strength of the flour is the ability of the flour to form dough, which, after kneading and during fermentation and proofing, has certain structural and mechanical properties, which subsequently determine certain indicators of the quality of bread. The flour with deformation work W between $9010^{-4} \mathrm{~J}$ and $16010^{-4} \mathrm{~J}$ is weak flour and absorption of water is low. Medium strength flour has a $\mathrm{W}$ of between $16010^{-4} \mathrm{~J}$ and $25010^{-4}$ $\mathrm{J}$ and absorbs more water. The flour with $\mathrm{W}$ between 250 $10^{-4} \mathrm{~J}$ and $31010^{-4} \mathrm{~J}$ is strong flour. Special flour has a W greater than $31010^{-4} \mathrm{~J}$ and absorbs very high quantity of water and is often used in mixes with other flour.

Flour samples that obtained from $\mathrm{C} 2 \mathrm{AA}, \mathrm{C} 2 \mathrm{AB}$ had the largest bread volume $-524 \mathrm{~cm}^{3}$ and $522 \mathrm{~cm}^{3}$, respectively, at the same time deformation work is relatively medium: C2AA - $24010^{-4} \mathrm{~J}, \mathrm{C} 2 \mathrm{AB}-24010^{-4} \mathrm{~J}$, $\mathrm{C} 6-20810^{-4} \mathrm{~J}$ whereas the highest rate of flour from the systems B4A, B4B, B5AB - $39010^{-4} \mathrm{~J}$ (Fig. 5).

\section{Conclusions}

A special place in the consumer market is occupied by the products of daily demand - bread and bakery products. In recent years there has been increasing in bakery production. In order to recommend certain types of flour for the production of any bakery products, you need to know the quality of the flour that produced from each system of the technological process of a flour mill and then mix the flour to obtain the end-use product of the required quality.

As a result of the research, it was determined that flour samples from the B5AB, B4B and B4A systems (break rolls) have the highest indicator of Wet Gluten Content, flour samples taken from the first reduction systems $\mathrm{C} 1 \mathrm{AC}(1), \mathrm{C} 1 \mathrm{AF}(1), \mathrm{C} 1 \mathrm{AC}(2)$ have the highest Whiteness from 69 to 71 units, respectively, the Ash content on these systems was low - from 0,37 to $0,36 \%$. The Water Absorbing Capacity of most of the samples have high enough indicators - from 55,0 to $69,7 \%$. Flour samples from systems $\mathrm{C} 4, \mathrm{C} 7$ and $\mathrm{C} 10$ have the highest rate of SD. 


\title{
REFERENCES
}

1. Martin, P., 2004. Controlling the bread making process: the role of bubbles in bread. Cereal Foods World, 49. pp. 72-75.

2. Sluimer, P., 2005. Principles of Breadmaking: Functionality of Raw Materials and Process Steps. American Association of Cereal Chemists, St. Paul. p. 212.

3. Fincher, G.B. and B.A. Stone. 1986. Cell wall and their components in cereal grain technology. In. Advances in Cereal Science and Technology. Pomeranz, Y. Ed. Am. Assoc. Cereal Chem., St.Paul, M.N. pp. 207-295.

4. Hoseney, RC., P. Wade and J.W. Finley. 1988. Soft wheat products. In Wheat Chemistry and Technology. Vol. 2. Pomeranz, Y. Ed. Am. Assoc. Cereal Chem. Inc. St. Paul, Minnesota, USA. pp. 407-456.

5. How Flour Affects Bread Quality. Lallemand Baking Update. Vol. 3, 17.

6. Weipert, D., 1997. Processing performance of rye as compared to wheat. Cereal Foods World, 42. pp. 706-712.

7. Pomeranz, Y. 1988. Chemical composition of kernel structures. In: Wheat Chemistry and Technology. Vol. 2. AACC International: St. Paul, MN. pp. 97-158.

8. Dornez, E., K. Gebruers, S. Wiame, J. A. Delcour and C. M. Courtin. (2006). Insight into the distribution of arabinoxylans, endoxylanases, and endoxylanase inhibitors in industrial wheat roller mill streams. Journal of Agricultural and Food Chemistry. 54. pp. 8521-8529.

9. Sutton, K. H. and L. D. Simmons (2006). Molecular level protein composition of flour mill streams from a pilot-scale flour mill and its relationship to product quality. Cereal Chemistry, 83, 1. pp. 52-56.

10. Dewettinck, K., F. Van Bockstaele, B. Kuhne, D. Van de Walle, T. M. Courtens and X. Gellynck. (2008). Nutritional value of bread: Influence of processing, food interaction and consumer perception. Journal of Cereal Science, 48. pp. 243-257.

11. Pomeranz, Y. Wheat: Chemistry and Technology; American Association of Cereal Chemists: St. Paul, MN, 1988; Vol. II.

12. Villanueva, R. M.; Leong, M. H.; Posner, E. S.; Ponte, J. G. Split milling of wheat for diverse end-use products. Cereal Foods World 2001, 46. pp. 363-369.

13. Aprodu I., Banu I., Stoenescu G., Ionescu V. Effect of the Industrial Milling Process on the Rheological Behavior of Different. St Cerc St CICBIA. 2010;11(4). pp. 429-437.

14. Fistes A., Soronja Simovic D., Rakic D., Mastilovic J. Statistical evaluation of different wheat and flour quality tests for predicting end-use performance. Acta Aliment [Internet]. 2013; 42 (3). pp. 349-359.

Д.О. ЖИГУНОВ ${ }^{1}$, д-р техн. наук, доцент, В.П. КОВАЛЬОВА ${ }^{1}$, аспірант, о.В. ДРАГОМИР ${ }^{1}$, Г.Д. ЖИГУНОВА ${ }^{2}$, магістр, К.К. ЖАНАБАЕВА ${ }^{3}$, старший викладач

${ }^{I}$ Одеська начіональна академія харчових технологій, м. Одеса

${ }^{2}$ Вищий інститут агробізнесу, м. Лілль, Франція

${ }^{3}$ Костанайський державний університет ім. Ахмета Байтурсинова, м. Костанай, Казахстан

\section{АНАЛІЗ ЯКОСТІ БОРОШНА З РІЗНИХ СИСТЕМ ТЕХНОЛОГІЧНОГО ПРОЦЕСУ БОРОШНОМЕЛЬНОГО ЗАВОДУ}

\begin{abstract}
Анотація
Метою дослідження є визначення якості борошна з різних систем технологічного процесу борошномельного заводу. Зразки борочна отримували на млині «Рівне Борошно». Приватне підприємство "Рівне Бороино" є одним з найбільших виробників пшеничного борошна в західному регіоні потужністю $180 \mathrm{~m} / 2 о б у$. Борошно, отримане з різних систем технологічного процесу, має дуже велику різноманітність показників якості. Оиінювалися білість, кількість та якість клейковини, вміст білка, вміст золи, водопоглинаюча здатність, число падіння, пошкодження крохмальних зерен, реологічні властивості тіста на приладі Міксолаб, а також якість хліба.

Під час дослідження було виявлено мінливість показників якості борошна на різних системах. Показник білості змінювався в діапазоні - від 1 до 71 од., ІДК - від 40 до 100 од., кількість клейковини - від 2 до $36 \%$, вміст білка - від 9,8 до 18,2\%, число падіння - від 275 до 374 с, пошкодження крохмальних зерен - від 15 до 30 , 3 UCD, вміст золи - від 0,31 до 2,23\%, водопоглинаюча здатність - від 53,5 до 69,7 \%.

У процесі подрібнення зерна та проміжних продуктів на млині виробляється більше двадияти потоків борошна різної якості. 3 цих потоків потрібно отримати тільки один або кілька сортів борошна. Зіичайно, якщо виробляється тільки один сорт, всі потоки об'єднуються. Середньозважені показники якості борошна повинні відповідати вимогам стандарту для изього сорту по вмісту золи, вмісту глютену тощо.

Максимальний вміст золи спостерігається у потоках з останніх розмельних систем, а також з систем драного процесу, де розмелюють продукти з великою кількістю оболонок. У той же час борошно 3 центральних частин ендосперму містить трохи менше клейковини, але більше крохмалю, ніж у борошні з периферичних частин ендосперму, які подрібнюються на наступних системах розмельного процесу.

Для дослідження були взяті зразки борошна з кожної системи технологічного процесу. Для зручності ми розташували їх за якістю, використовуючи показник білості. Одним з основних показників якості борошна, щзо визначає його сорт, є білість. У досліджуваних зразках значення показника білості становить від 1 до 71 одиниці.
\end{abstract}

Ключові слова: якість борочна, борочно пшеничне, показники якості, клейковина, білок, число падіння, пошкодження крохмальних зерен. 


\title{
ЛІТЕРАТУР
}

1. Martin, P., 2004. Controlling the bread making process: the role of bubbles in bread. Cereal Foods World 49. pp. 72-75.

2. Sluimer, P., 2005. Principles of Breadmaking: Functionality of Raw Materials and Process Steps. American Association of Cereal Chemists, St. Paul. p. 212.

3. Fincher, G.B. and B.A. Stone. 1986. Cell wall and their components in cereal grain technology. In. Advances in Cereal Science and Technology. Pomeranz, Y. Ed. Am. Assoc. Cereal Chem., St.Paul, M.N. pp. 207-295.

4. Hoseney, RC., P. Wade and J.W. Finley. 1988. Soft wheat products. In Wheat Chemistry and Technology. Vol. 2. Pomeranz, Y. Ed. Am. Assoc. Cereal Chem. Inc. St. Paul, Minnesota, USA. pp. 407-456.

5. How Flour Affects Bread Quality. Lallemand Baking Update, Vol. 3, 17.

6. Weipert, D., 1997. Processing performance of rye as compared to wheat. Cereal Foods World, 42. pp. 706-712.

7. Pomeranz, Y. 1988. Chemical composition of kernel structures. In: Wheat Chemistry and Technology. Vol. 2. AACC International: St. Paul, MN. Pp. 97-158.

8. Dornez, E., K. Gebruers, S. Wiame, J. A. Delcour and C. M. Courtin. (2006). Insight into the distribution of arabinoxylans, endoxylanases, and endoxylanase inhibitors in industrial wheat roller mill streams. Journal of Agricultural and Food Chemistry, 54. pp. 8521-8529.

9. Sutton, K. H. and L. D. Simmons (2006). Molecular level protein composition of flour mill streams from a pilot-scale flour mill and its relationship to product quality. Cereal Chemistry, 83, 1. pp. 52-56.

10. Dewettinck, K., F. Van Bockstaele, B. Kuhne, D. Van de Walle, T. M. Courtens and X. Gellynck. (2008). Nutritional value of bread: Influence of processing, food interaction and consumer perception. Journal of Cereal Science, 48. pp. 243-257.

11. Pomeranz, Y. Wheat: Chemistry and Technology; American Association of Cereal Chemists: St. Paul, MN, 1988; Vol. II.

12. Villanueva, R. M.; Leong, M. H.; Posner, E. S.; Ponte, J. G. Split milling of wheat for diverse end-use products. Cereal Foods World 2001, 46. pp. 363-369.

13. Aprodu I., Banu I., Stoenescu G., Ionescu V. Effect of the Industrial Milling Process on the Rheological Behavior of Different. St Cerc St CICBIA. 2010;11(4). pp. 429-437.

14. Fistes A., Soronja Simovic D., Rakic D., Mastilovic J. Statistical evaluation of different wheat and flour quality tests for predicting end-use performance. Acta Aliment [Internet]. 2013; 42 (3). pp. 349-359.

Надійшла 02.02.2019. До друку 25.02.2019.

Рецензія 10.02.2019

Адреса для переписки:

65039, Odessa, str. Kanatnaya 112

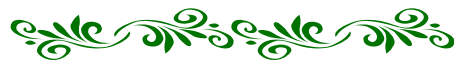

UDK 664.785

O.I. SHAPOVALENKO, Dr. tech. sc., professor National university of food technologies, Odessa, Ukraine

I.O. KUSTOV, PhD tech. sc., senior lecturer Odessa National Academy of Food Technologies, Odessa, Ukraine R.S. RIBCHINSKIY, the head of the public union "Millers of Ukraine"

\section{FEATURES OF CORN CONSUMPTION IN THE FOOD PRODUCTION INDUSTRY}

\begin{abstract}
Анотація
This paper presents the features of corn as raw material for groat industry. Corn is used in many segments of the food and processing industry. corn is processed for traditional food products - groats, flakes, flour, extruded foods, and other corn byproducts are widely used for the production of dry breakfast cereals, snacks, cereal bars. In terms of using of the advanced processing technologies, the industry produces starch, gluten, and germs. Corn germ is used to produce the high-value vegetable oil, as well as starch - for both food and non-food purposes. More than half (65\%) of corn is used for feed purposes, 25\%-technical purposes, and nearly 20\% - for various types of food production. corn is processed for traditional food products - groats, flakes, flour, extruded foods, and other corn by-products are widely used for the production of dry breakfast cereals, snacks, cereal bars. For the colour, corn is divided into white and yellow types. According to the literature data analysis, yellow corn is more used in China, Argentina, Brazil, while white corn - in some countries of Asia, Latin America, and the Balkan countries. Depending on its morphological features, the corn kernelis divided into various groups, species and subspecies.

In Ukraine corn kernel is classified into 8 types, with separately defined limitations on the content of the major crop in the batch, grains of other type, etc. Corn of I-VIII types with the quality indicators specified in the standard, for the production of food products. Flint and dent corn types are the most applied grain varieties in the industry, they are widely used in the production segment of food and feed products. Sweet corn is widely used as a vegetable crop in the food canning, food concentrates, starch and brewing industries due to its flavor properties. Popped corn is not only the most convenient raw material for the production of popcorn, but it also can be used as the raw material for the production of corn curls and dry breakfast cereals By analyzing the weight fraction of fat in kernels of different corn varieties we can note that the lowest number of fat is typical for popped corn (4.0\%) and the largest - for sweet corn (9.1\%); dent and flint corn have the same total fat number (4.5-4.9\%). Test weight of corn types - popped corn ranges within 712-826 g/l, dent corn - 875-893 g/l, and flint corn - 768-786 g/l. The weight of 1000 kernels of corn depending on the varieties changes within $150-600 \mathrm{~g}$.
\end{abstract}

Keywords: groat industry, corn, chemical composition, technological properties, processing. 